\title{
Early development of Negro and White babies
}

\author{
MARGARET POLLAK and SUSAN MITCHELL \\ From General Practice, London S.W.4, and King's College Hospital Medical School
}

\begin{abstract}
Pollak, M., and Mitchell, S. (1974). Archives of Disease in Childhood, 49, 40. Early development of Negro and White babies. Seventy-five babies, 25 English, 25 West Indian, and 25 Cypriot, all born in London, were examined at 1, 3, and 9 months of age on Gesell and Sheridan scales. The age of walking alone was measured. All the babies were term normal deliveries, weighing $2500 \mathrm{~g}$ or more. They were examined under identical conditions. A statistically significant acceleration in gross motor function was found in the West Indian infants at 1 month, compared with the English and Cypriot infants. The acceleration related to extension. At 3 months all three groups were at the same developmental level, and at 9 months both the English and Cypriot babies were ahead of the West Indian infants in adaptive, language, and personal-social development. No significant difference in mean age of walking between the three groups was found.
\end{abstract}

The development of the Negro infant has been the subject of a number of conflicting reports. An acceleration of gross motor function has been claimed by some studies (Curti, Marshall, and Steggerda, 1935; Bayley, 1965; GranthamMcGregor and Back, 1971); others (Geber and Dean, 1957, 1964) have claimed a global precocity; early walking has been noted (Geber and Dean, 1957, 1964; Hood et al., 1970); yet others (McGraw, 1931; Pasamanick and Knobloch, 1953; Knobloch, 1958) have not confirmed these findings.

\section{Methods}

We report a study of the early development of 75 English, West Indian, and Cypriot (Turkish and Greek) children, born and living in London. All fathers were in social classes IV and V (Registrar General's classification). All were term normal deliveries, weighing $2500 \mathrm{~g}$ or over. Not all mothers were primipara. The sample was drawn from the practice population, being the first 25 babies in each category born on or after 1 January 1970. The sex distribution was English, 11 males 14 females; West Indian, 12 males 13 females; and Cypriot, 13 males 12 females.

Each baby was seen at 1,3, and 9 calendar months of life ( \pm 3 days) and later, at varying times, to estimate their age of walking. All were examined by one or the other of us, but the same baby was not necessarily examined by the same doctor at subsequent examinations. The infants were seen either in their own homes or at the practice premises. The examinations took a structured course, followed a prearranged schedule, and the results were recorded immediately after comple-

Received 16 July 1973. tion of the test. For the most part, the tests were those described by Illingworth (1960) and thus derive from Gesell and Amatruda (1947), but Sheridan (1958, 1969) tests of vision and hearing were included. The schedules and methods of scoring for the three age groups are given in Tables I-III.

\section{Results}

All the babies were examined during the prescribed time and all 225 examinations were completed. The results are shown in Tables IV-VII.

\section{Discussion}

A comparison of the English and Cypriot infants reveals only 2 significantly different scores. At 3 months fewer Cypriot babies are laughing aloud, while at 9 months more Cypriot babies can walk with only one hand held. When the West Indian and English babies are compared, the reported early gross motor precocity of the Negro baby is confirmed. At 1 month the West Indian baby is highly significantly in advance in his ability to open his hands and in control of head, neck, and back muscles. In the prone position, his gross motor control is found to be superior and he is more mature in both suspended prone and supine positions. This precocity has disappeared by 3 months and does not reappear at 9 months. In particular, this study found no evidence of early walking, and we are unable to confirm the precocity of the Negro baby in other areas of development. On the contrary, the social behaviour of English and Cypriot babies was found to be superior at 1 month and highly 
TABLE I

Schedule of examination at 1 month

\begin{tabular}{|c|c|c|c|}
\hline Test no. & Category & Description & Score \\
\hline 1 & Position (supine) & $\begin{array}{l}\text { Head on side } \\
\text { Head sometimes midline } \\
\text { Head midline }\end{array}$ & $\begin{array}{l}1 \\
2 \\
3\end{array}$ \\
\hline 2 & Hands & $\begin{array}{l}\text { Closely fisted } \\
\text { Sometimes open } \\
\text { Always open }\end{array}$ & $\begin{array}{l}1 \\
2 \\
3\end{array}$ \\
\hline 3 & Pull to sit & $\begin{array}{l}\text { No head control, head and back in one curve } \\
\text { Slight head control, back straightening } \\
\text { Head erect before bobbing forward and back straightening }\end{array}$ & $\begin{array}{l}1 \\
2 \\
3\end{array}$ \\
\hline 4 & Walking reflex & $\begin{array}{l}\text { Present } \\
\text { Absent }\end{array}$ & $\begin{array}{l}1 \\
2\end{array}$ \\
\hline 5 & Prone, hands under abdomen & $\begin{array}{l}\text { Head droops } \\
\text { Head and back in straight line } \\
\text { Head above straight line }\end{array}$ & $\begin{array}{l}1 \\
2 \\
3\end{array}$ \\
\hline 6 & Prone & $\begin{array}{l}\text { Head on side, buttocks humped, arms and legs flexed } \\
\text { Head midline, buttocks extended } \\
\text { Head off couch, buttocks flat, legs extended }\end{array}$ & $\begin{array}{l}1 \\
2 \\
3\end{array}$ \\
\hline 7 & Vision & $\begin{array}{l}\text { Follows ring through } 45^{\circ} \\
\text { Follows ring through } 90^{\circ} \\
\text { Follows ring through } 180^{\circ}\end{array}$ & $\begin{array}{l}1 \\
2 \\
3\end{array}$ \\
\hline 8 & Hearing & $\begin{array}{l}\text { Quiets to bell } \\
\text { Turns head to bell }\end{array}$ & $\begin{array}{l}1 \\
2\end{array}$ \\
\hline 9 & Social & $\begin{array}{l}\text { Regards mother when she talks } \\
\text { Smiles at mother }\end{array}$ & $\begin{array}{l}1 \\
2\end{array}$ \\
\hline
\end{tabular}

Note: All the tests were scored from clinical observations. Test 9 was carried out by asking the mother, with the baby in her arms, to talk to the baby and then by asking her, 'Make him smile', by whatever method she had at her disposal.

significantly so at 9 months. At 3 months the English baby is in advance of the West Indian in language development, and by 9 months both English and Cypriot infants are superior in language and adaptive development. Compared with the English infant, the Cypriot baby shows almost no differences, yet when compared with the West Indian infant he is found to be in an intermediate position. Though the gross motor function of the West Indian is in advance, the precocity is less marked than between the West Indian and English. The Cypriot baby is in advance of both groups in ability to stand on his feet at 3 months, and he is auditorily more aware. He shares with the English baby a precocity in social behaviour at 1 and 9 months, and in language development at 9 months. Thus, this study presents evidence that early motor function of the Negro baby is advanced compared with that of his Caucasian brother, but that this advance has disappeared by the age of 3 months. This advanced development relates to extension and therefore is helpful in achieving the prone position. The absence of advanced flexion or hyperextension presumably accounts for the absence of early sitting or standing before sitting.
The age at which the precocity disappears is earlier than has been noted in previous studies and perhaps the presence of comparable controls and a third group has proved helpful. No doubt the difficulty of finding suitable numbers of White babies in Uganda explains the absence of controls in the studies of Geber and Dean $(1957,1964)$. Both Curti et al. (1935) and Grantham-McGregor and Back (1971) had to rely upon Gesell's White norms as controls, while the White children in the studies of Pasamanick (1946) and Pasamanick and Knobloch (1953) were not examined under rigidly similar conditions to the Negro sample. It is interesting that the same authors, in a further study (Knobloch and Pasamanick, 1958) when only term White and Negro babies were compared under similar conditions, found no significant differences between the two groups. On the other hand, Bayley (1965) compared White and Negro groups (and a subsample of Puerto Ricans) under identical conditions and found higher Negro scores up to 12 months of age.

Various explanations have been offered for the precocity of Negro babies. For example, a more permissive attitude towards child rearing has been 
TABLE II

Schedule of examination at 3 months

\begin{tabular}{|c|c|c|c|}
\hline Test no. & Category & Description & Score \\
\hline 1 & Position (supine) & $\begin{array}{l}\text { Head half side } \\
\text { Head midline } \\
\text { Can lift head off couch }\end{array}$ & $\begin{array}{l}1 \\
2 \\
3\end{array}$ \\
\hline 2 & Hands & $\begin{array}{l}\text { Grasp reflex absent } \\
\text { Hands open }\end{array}$ & $\begin{array}{l}1 \\
2\end{array}$ \\
\hline 3 & Pull to sit & $\begin{array}{l}\text { Head lags } \\
\text { No head lag } \\
\text { Flexes neck muscles }\end{array}$ & $\begin{array}{l}1 \\
2 \\
3\end{array}$ \\
\hline 4 & Sitting & $\begin{array}{l}\text { Head set forward, but bobs } \\
\text { Head set forward but steady } \\
\text { Head erect and steady } \\
\text { Sits alone briefly or leans on hands }\end{array}$ & $\begin{array}{l}1 \\
2 \\
3 \\
4\end{array}$ \\
\hline 5 & Prone & $\begin{array}{l}\text { Chin and shoulders off couch } \\
\text { Chin and shoulders off couch and weight on forearms } \\
\text { Takes weight on extended arms }\end{array}$ & $\begin{array}{l}1 \\
2 \\
3\end{array}$ \\
\hline 6 & Standing & $\begin{array}{l}\text { Stands with shoulders supported } \\
\text { Stands with two hands held } \\
\text { Stands with one hand held }\end{array}$ & $\begin{array}{l}1 \\
2 \\
3\end{array}$ \\
\hline 7 & Hearing & $\begin{array}{l}\text { Turns to voice, either side } \\
\text { Turns to rattle } \\
\text { Turns to bell }\end{array}$ & $\begin{array}{l}1 \\
1 \\
1\end{array}$ \\
\hline 8 & Vision & $\begin{array}{l}\text { Watches dangling ring through } 180^{\circ} \\
\text { Watches dangling ring upwards } \\
\text { Tries to grasp ring }\end{array}$ & $\begin{array}{l}1 \\
2 \\
3\end{array}$ \\
\hline 9 & Rolling toy & $\begin{array}{l}\text { Watches toy but not when falls } \\
\text { Watches and follows when toy falls }\end{array}$ & $\begin{array}{l}1 \\
2\end{array}$ \\
\hline 10 & Rattle & $\begin{array}{l}\text { Holds rattle in hand } \\
\text { Waves rattle } \\
\text { Brings hands to midline to grasp rattle }\end{array}$ & $\begin{array}{l}1 \\
2 \\
3\end{array}$ \\
\hline 11 & Language & $\begin{array}{l}\text { Making noises } \\
\text { Laughs aloud }\end{array}$ & $\begin{array}{l}1 \\
2\end{array}$ \\
\hline 12 & Social & $\begin{array}{l}\text { Smiles at mother } \\
\text { Smiles at doll's head }\end{array}$ & $\begin{array}{l}1 \\
2\end{array}$ \\
\hline
\end{tabular}

Note: With the exception of test 11 , all were observed results. Test 11 relied upon the mother's observations which were, in some cases, confirmed by clinical observation.

suggested (Knobloch and Pasamanick, 1958; Williams and Scott, 1953); and Ainsworth (1967), commenting upon the findings of Geber and Dean (1964), suggested close physical contact between mother and child; lower socioeconomic class has been indicated (Williams and Scott, 1953; Pavenstedt 1965). We think that the evidence is against these explanations. For example, we found no evidence of closer physical contact or permissiveness in West Indian parents, nor was breast feeding more common. The class distribution of the three groups was similar. Following the prevailing mood, most writers have been at pains to explain the differences on any but racial grounds (Knobloch and Pasamanick, 1958; Williams and Scott, 1953; Davis and Havighurst, 1946; Ferron, 1967). On the other hand, Illingworth (1960) suggested that there may be differences in certain races. Bayley (1965) attributes differences to both inherent and envrionmental differences. If differences in development are not due to ethnic variations, then differing child rearing practices must be considered. It seems reasonable to assume that the varying factors will include opportunity, experience, and parental expectation, and the effects will vary with age and aspect of development studied. It is difficult to imagine how-or why-a laissez-faire attitude by parents could result in early head control in a month-old baby. However, at a later date, cultural patterns might well be expected to affect adaptive 
Early development of Negro and White babies

TABLE III

Schedule of examination at 9 months

\begin{tabular}{|c|c|c|c|}
\hline Test no. & Category & Description & Score \\
\hline 1 & Sitting & $\begin{array}{l}\text { Sits steady } \\
\text { Sits steady, reaches forward for rattle and re-erects } \\
\text { Sits steady and can turn } 60^{\circ} \text { back to get rattle from ground level } \\
\text { and re-erect }\end{array}$ & $\begin{array}{l}1 \\
2 \\
3\end{array}$ \\
\hline 2 & Standing & $\begin{array}{l}\text { Holds rail, full weight on feet } \\
\text { Can pull to feet at rail } \\
\text { Can pull to feet, stand at rail, and reach for toy with one hand } \\
\text { Can cruise at rail }\end{array}$ & $\begin{array}{l}1 \\
2 \\
3 \\
4\end{array}$ \\
\hline 3 & Progression & $\begin{array}{l}\text { Crawls } \\
\text { Creeps } \\
\text { Walks, two hands held } \\
\text { Walks, one hand held } \\
\text { Walks alone } \\
\text { Shuffles }\end{array}$ & $\begin{array}{l}1 \\
2 \\
3 \\
4 \\
5 \\
1\end{array}$ \\
\hline 5 & Cube and cup & $\begin{array}{l}\text { Brings cube near to cup } \\
\text { Cube into cup, no release } \\
\text { Cube into cup and release }\end{array}$ & $\begin{array}{l}1 \\
2 \\
3\end{array}$ \\
\hline 6 & Pellet & $\begin{array}{l}\text { Rakes at pellet } \\
\text { Intermediate grasp } \\
\text { 'Pincer' pellet }\end{array}$ & $\begin{array}{l}1 \\
2 \\
3\end{array}$ \\
\hline 7 & Language & $\begin{array}{l}\text { Making sounds, no words } \\
\text { Says one word } \\
\text { Says two words } \\
\text { Says three words }\end{array}$ & $\begin{array}{l}0 \\
1 \\
2 \\
3\end{array}$ \\
\hline 8 & Social & $\begin{array}{l}\text { Drinks from a cup } \\
\text { Waves 'bye-bye' } \\
\text { Eats proffered biscuit }\end{array}$ & $\begin{array}{l}1 \\
1 \\
1\end{array}$ \\
\hline 10 & Hearing & Responds to all Sheridan (1958) hearing tests & 0 \\
\hline
\end{tabular}

Note: All were observed results with the exception of test 7 which sometimes relied upon the mother's word.

and language development. Mead's (1930) description of the upbringing of the Manus children is a graphic account of cultural patterns and parental expectations affecting future adults. Pollak (1973) showed that West Indian immigrant children lack stimulation and close mother-child contact. This may be the explanation of the lower achievement of the West Indian babies in language and adaptive

TABLE IV

Actual mean scores at 1 month

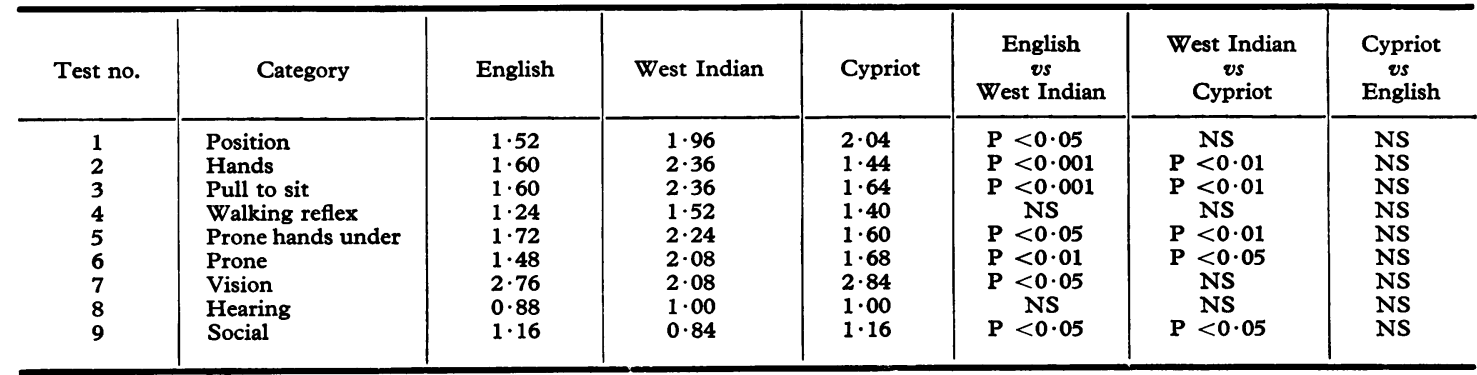

NS, not significant. 
TABLE V

Actual mean scores at 3 months

\begin{tabular}{|c|c|c|c|c|c|c|c|}
\hline Test no. & Category & English & West Indian & Cypriot & $\begin{array}{c}\text { English } \\
\quad v s \\
\text { West Indian }\end{array}$ & $\begin{array}{c}\text { West Indian } \\
\text { vs } \\
\text { Cypriot }\end{array}$ & $\begin{array}{c}\text { Cypriot } \\
v s \\
\text { English }\end{array}$ \\
\hline $\begin{array}{r}1 \\
2 \\
3 \\
4 \\
5 \\
6 \\
7 \\
8 \\
9 \\
10 \\
11 \\
12\end{array}$ & $\begin{array}{l}\text { Position } \\
\text { Hands } \\
\text { Pull to sit } \\
\text { Sitting } \\
\text { Prone } \\
\text { Standing } \\
\text { Hearing } \\
\text { Vision } \\
\text { Rolling toy } \\
\text { Rattle } \\
\text { Language } \\
\text { Social }\end{array}$ & $\begin{array}{l}1 \cdot 84 \\
1 \cdot 80 \\
2 \cdot 12 \\
2 \cdot 00 \\
1 \cdot 32 \\
1 \cdot 28 \\
1 \cdot 28 \\
1 \cdot 04 \\
1 \cdot 04 \\
1 \cdot 20 \\
1 \cdot 80 \\
1 \cdot 44\end{array}$ & $\begin{array}{l}2 \cdot 12 \\
1 \cdot 72 \\
2 \cdot 12 \\
2 \cdot 40 \\
1 \cdot 64 \\
0 \cdot 64 \\
0 \cdot 68 \\
1 \cdot 12 \\
1 \cdot 00 \\
1 \cdot 20 \\
1 \cdot 32 \\
1 \cdot 32\end{array}$ & $\begin{array}{l}1 \cdot 96 \\
1 \cdot 80 \\
2 \cdot 00 \\
2 \cdot 28 \\
1 \cdot 60 \\
1 \cdot 40 \\
1 \cdot 40 \\
1 \cdot 00 \\
1 \cdot 00 \\
1 \cdot 16 \\
1 \cdot 56 \\
1 \cdot 56\end{array}$ & $\begin{array}{l}\text { NS } \\
\text { NS } \\
\text { NS } \\
\text { NS } \\
\text { NS } \\
\text { NS } \\
\text { NS } \\
\text { NS } \\
\text { NS } \\
\text { NS } \\
P \text { <0.01 } \\
\text { NS }\end{array}$ & $\begin{array}{l}\text { NS } \\
\text { NS } \\
\text { NS } \\
\text { NS } \\
\text { NS } \\
P<0.05 \\
P<0.05 \\
\text { NS } \\
\text { NS } \\
\text { NS } \\
\text { NS } \\
\text { NS }\end{array}$ & $\begin{array}{l}\text { NS } \\
\text { NS } \\
\text { NS } \\
\text { NS } \\
\text { NS } \\
\text { NS } \\
\text { NS } \\
\text { NS } \\
\text { NS } \\
\text { NS } \\
P<0 \cdot 05 \\
\text { NS }\end{array}$ \\
\hline
\end{tabular}

NS, not significant.

TABLE VI

Actual mean scores at 9 months

\begin{tabular}{|c|c|c|c|c|c|c|c|}
\hline Test no. & Category & English & West Indian & Cypriot & $\begin{array}{c}\text { English } \\
\text { vs } \\
\text { West Indian }\end{array}$ & $\begin{array}{c}\text { West Indian } \\
\text { vs } \\
\text { Cypriot }\end{array}$ & $\begin{array}{c}\text { Cypriot } \\
\text { vs } \\
\text { English }\end{array}$ \\
\hline $\begin{array}{l}1 \\
2 \\
3 \\
4 \\
5 \\
6 \\
7 \\
8\end{array}$ & $\begin{array}{l}\text { Sitting } \\
\text { Standing } \\
\text { Progression } \\
\text { Cube } \\
\text { Cube and cup } \\
\text { Pellet } \\
\text { Language } \\
\text { Social }\end{array}$ & $\begin{array}{l}2 \cdot 96 \\
2 \cdot 24 \\
0 \cdot 68 \\
2 \cdot 00 \\
1 \cdot 44 \\
2 \cdot 24 \\
1 \cdot 56 \\
0 \cdot 96\end{array}$ & $\begin{array}{l}2 \cdot 92 \\
2 \cdot 68 \\
0 \cdot 84 \\
1 \cdot 56 \\
0 \cdot 84 \\
2 \cdot 12 \\
0 \cdot 60 \\
0 \cdot 32\end{array}$ & $\begin{array}{l}2 \cdot 96 \\
2 \cdot 56 \\
0 \cdot 92 \\
2 \cdot 36 \\
1 \cdot 28 \\
2 \cdot 24 \\
1 \cdot 24 \\
0 \cdot 92\end{array}$ & $\begin{array}{c}\text { NS } \\
\text { NS } \\
\text { NS } \\
\text { NS } \\
P<0.01 \\
\text { NS } \\
P<0.01 \\
P<0.001\end{array}$ & $\begin{array}{c}\text { NS } \\
\text { NS } \\
\text { NS } \\
P<0.001 \\
P<0.05 \\
P< \\
N S \\
P<0.05 \\
P<0.001\end{array}$ & $\begin{array}{l}\text { NS } \\
\text { NS } \\
<0 \cdot 05 \\
\text { NS } \\
\text { NS } \\
\text { NS } \\
\text { NS } \\
\text { NS }\end{array}$ \\
\hline
\end{tabular}

NS, not significant.

Note: All 25 babies in each group focused on all sizes of rolling balls. All but 2 Cypriot babies responded to all the hearing tests, and these 2 responded to 4 out of 5 tests.

TABLE VII

Walking alone

\begin{tabular}{l|c|c|c}
\hline & English & West Indian & Cypriot \\
\hline $\begin{array}{c}\text { No. of children seen to be } \\
\text { walking alone at } 12 \text { mth } \\
( \pm 7 \text { dy) }\end{array}$ & 12 & 13 & 11 \\
$\begin{array}{c}\text { Actual mean age of walking } \\
\text { alone (mth) }\end{array}$ & $12 \cdot 8$ & $12 \cdot 7$ & 12.9 \\
\hline
\end{tabular}

Note: There are no significant differences between the mean age of walking in the three groups.

development. Geber and Dean (1964) put forward this postulate to explain the later regression of the Ugandan children. Yet these explanations only serve to show that development as a whole can never be equated with the sum of the mean achievement in the various types of development; they do not explain the motor advancement in the early life of the Negro baby. Perhaps we should agree that
Illingworth (1960) is right, and there are marginal differences between some ethnic groups at birth.

We thank the Statistical Unit of the Royal College of General Practitioners for statistical advice.

\section{REFERENCES}

Ainsworth, M. (1967). Infancy in Uganda, p. 73. Johns Hopkins Press, Baltimore.

Bayley, N. (1965). Comparisons of mental and motor test scores for ages 1-15 months by sex, birth order, race, geographical location, and education of parents. Child Development, 36, 379 .

Curti, M., Marshall, F. B., and Steggerda, M. (1935). The Gesell schedules applied to 1,2 and 3 year old negro children of Jamaica. Fournal of Comparative Psychology, 20, 125.

Davis, A., and Havighurst, R. J. (1946). Social class and color differences in child rearing. American Sociology Review, 11, 698.

Ferron, O. M. (1967). The effects of early environmental stimulation amongst Freetown Creoles. A comparative study. O.M.E.P. Newsletter, 2, 17.

Geber, M., and Dean, R. F. (1957). Gesell tests on African children. Pediatrics, 20, 1055.

Geber, M., and Dean, R. F. (1964). Le développement psychomoteur et somatique des jeunes enfants Africains en Ouganda. Courrier, 14, 425. 
Gesell, A., and Amatruda, C. S. (1947). Developmental Diagrams. Harper and Row, New York.

Grantham-McGregor, S. M., and Back, E. H. (1971). Gross motor development in Jamaican infants. Developmental Medicine and Child Neurology, 13, 79.

Hood, C., Oppé, T., Pless, L., and Apte, E. (1970). Children of West Indian Immigrants, p. 29. Institute of Race Relations, London.

Illingworth, R. S. (1960). The Development of the Infant and Young Child, p. 190. Livingstone, Edinburgh.

Knobloch, H. (1958). The precocity of African children. Pediatrics, 22, 601.

Knobloch, H., and Pasamanick, B. (1958). The relationship of race and socioeconomic status to the development of motor behavior patterns in infancy. In Social Aspects of Psychiatry. Psychiatric Research Reports, Vol. 10, p. 123. Ed. by B. Pasamanick and P. H. Knapp. American Psychiatric Association, Washington.

McGraw, M. B. (1931). A comparative study of a group of Southern white and negro infants. Genetic Psychology Monographs, 10, 1.

Mead, M. (1930). Growing up in New Guinea. Penguin Books, Harmondsworth, Middlesex.

Pasamanick, B. (1946). A comparative study of the behavioural development of negro infants. Fournal of Genetic Psychology, 69, 3.
Pasamanick, B., and Knobloch, H. (1953). Further observations on the behavioural development of negro children. fournal of Genetic Psychology, 83, 137.

Pavenstedt, E. (1965). A comparison of the child-rearing environment of upper-lower and very low-lower class families. American fournal of Orthopsychiatry, 35, 89.

Pollak, M. (1973). Today's Three Year Olds in London, p. 21. Heinemann Medical Books, London.

Sheridan, M. (1958). Simple clinical hearing-tests for very young or mentally retarded children. British Medical fournal, 2, 999.

Sheridan, M. (1969). Vision screening procedures for very young or handicapped children. In Aspects of Developmental and Paediatric Ophthalmology. Clinics in Developmental Medicine, No. 32, p. 39. Ed. by P. Gardiner, R. Mac Keith, and V. Smith. Heinemann, London.

Williams, J. R., and Scott, R. B. (1953). Growth and development of negro infants. Motor development and its relationship to child rearing practices, in 2 groups of negro infants. Child Development, 24, 103.

Correspondence to Dr. M. Pollak, 8 Macaulay Road, London S.W.4. 